\title{
Etnik Farklılık ve Kamu Borcu Üzerine Etkileri: Analitik Bir Bakış Açısı
}

Aylin KONU, Department of International Trade and Logistics, Faculty of Economics and Administrative Sciences, Gaziantep University, Turkey; e-mail: akoc@gantep.edu.tr

Ahmet Yulmaz ATA, Department of Economics, Faculty of Economics and Administrative Sciences, Gaziantep University, Turkey; e-mail: ayata@gantep.edu.tr

\section{Ethnic Diversity and Effects on Public Debt: An Analytical Point of View}

\begin{abstract}
Nowadays, public debt is one of the most important macroeconomic problems encounted in developed or developing countries. In addition to the economic factors, social and institutional factors may also affect public debt. It is expressed that the ethnic diversity is one of the social factors that influence the public debt by increasing public spending. The purpose of this paper is to empirically test to the impact of ethnic diversity on public debt for the $28 \mathrm{EU}$ countries and Turkey by using 2014 data and cross-section analysis method. According to the empirical results of the study, it was found that ethnic diversity had statistically significant and positive impact on public debt.

Keywords : Diversity, Public Debt, Rent-Seeking.

JEL Classification Codes : D02, D73, O11, C21.

\section{Öz}

Kamu borçları günümüzde gelişmiş ya da gelişmekte olan birçok ülkede en önemli makroekonomik sorunların başında gelmektedir. Ekonomik faktörlerin yanı sıra, sosyal ve kurumsal faktörler de kamu borçlarını etkileyebilmektedir. Etnik farklılık olgusu, kamu harcamalarını artırmak suretiyle kamu borcunu etkileyen sosyal unsurlardan biri olarak ortaya çıkmaktadır. Bu çalışmanın amacı, etnik farklılığın kamu borcu üzerindeki etkisini 28 AB ülkesi ve Türkiye için 2014 verilerini kullanarak yatay-kesit analiz yöntemi ile test etmektir. Çalışmadan elde edilen ampirik sonuçlara göre, etnik farklılığın kamu borcu üzerinde istatistiksel olarak anlamlı ve pozitif yönlü bir etkiye sahip olduğu bulgusuna ulaşılmıştır.
\end{abstract}

Anahtar Sözcükler $\quad$ : Etnik Farklılık, Kamu Borçları, Rant Kollama. 


\section{Giriş}

Belirli bir dönem içerisinde kamu gelirleri ile kamu giderleri arasındaki fark olarak tanımlanan kamu açığının varlığı, kamunun borçlanma gereksinimine yol açar ve bu şekilde kamu borcu ortaya çıkar. Kamu borcunun varlığ 1 , gerek gelişmiş, gerekse gelişmekte olan ülkelerde farklı boyutlarda olmak üzere makroekonomik dengeler üzerinde olumsuz sonuçlara yol açan önemli bir ekonomik ve mali problem olarak görülmektedir (Şahbaz, vd., 2013: 206). Tarihsel süreç içerisinde devlet anlayışında meydana gelen değişmeler kamu borçlarının artmasında etkili olan en önemli faktörler arasında yer almaktadır. 1929 Ekonomik Krizi'nden sonraki dönemde, müdahaleci devlet anlayışının egemen olması ile birlikte, devletin fonksiyonlarında meydana gelen artışa bağlı olarak kamu harcamaları da hızla artmaya başlamıştır. Kamu gelirleri, artan bu kamu harcamalarını karşılayacak düzeyde olmayınca, kamu borçlanma gereksinimini ortaya çıkmıştır. Özellikle, 1970’li yılların başlarından itibaren etkisini göstermeye başlayan petrol şokları sonrasında stagflasyonist eğilimler sonucu kamu borcunun varlığı ve sürdürülebilirliği önemli ve kronik bir sorun olarak ortaya çıkmıştır (Woo, 2003: 2).

Günümüzde, birçok dünya ülkesinin, ekonomik kriz yaşamalarının en önemli nedeni olarak, yüksek kamu borç miktarı olduğu ifade edilmektedir. Bu kapsamda, gerek uluslararası kuruluşlar gerekse bilim adamları yüksek kamu borçlarının azaltılması ve bu doğrultuda ekonomik, politik ve sosyal tedbirlerin alınması yönünde uyarılarda bulunmaktadır. Kamu borçlarının azaltılması yönündeki en etkin yol, bu borca yol açan unsurları ortadan kaldırmaktır. Nasıl ki herhangi bir sorunun çözülebilmesi için sorunu meydana getiren sebeplerin ortadan kaldırılması gerekirse kamu borçlarının azaltılması yönünde atılacak en etkin adım, bu borca yol açan unsurların iyi analiz edilip ortaya çıkarılmasıdır.

"Kamu borçlarının nedenleri”, üzerine oluşturulan çalışmalarda, son dönemlere kadar, sadece ekonomik faktörler ele alınırken, günümüzde ekonomik faktörlerle birlikte ekonomik dışı faktörler olarak politik, sosyal ve kurumsal faktörler de araştırılmakta ve bu çalışmalar, kamu borçlarının azaltılması noktasında önemli yol gösterici ipuçları sunmaktadır. Kamu borçlarının belirleyicileri üzerine son zamanlarda yapılan bu çalışmalar, kamu borçlarının çok büyük oranda politik ve kurumsal faktörler tarafından belirlendiğini ortaya koymaktadır (Woo, 2003: 2; Şahbaz, vd., 2013: 207).

Kamu borcunun, sosyal ve demografik unsurları bağlamında ele alınan unsurlardan bir tanesi, "etnik farklılık" kavramıdır. Etnik farklılığın yüksek ve iktisat politikalarının saptanmasında önemli bir gösterge olduğu toplumlarda, devlet daha müdahaleci olmakla birlikte, sosyal açıdan en iyi politikaları seçme olasılığının daha düşük olduğu belirtilmektedir. Yüksek etnik farklılığın varlığı, ekonomik büyüme ve kalkınmayı yavaşlattığı, kamu borçlarını artırdığı ifade edilmektedir (Montalvo \& Querol, 2005: 293). $\mathrm{Bu}$ çerçevede, etnik farklılık düzeyi ile kamu borçları arasında bir ilişkinin varlığından söz edilmektedir. Buna göre, yüksek etnik farklılık, kamu harcamalarında verimsizliğe yol açarak, kamu harcama miktarının artmasına ve aynı zamanda vergi gelir kayıplarına yol 
açarak kamu gelirlerinde bir azalmaya yol açabilmektedir. Kısacası, etnik farklılığın yüksek olduğu heterojen toplumlarda, sağlıklı mali politikalar oluşturulması imkânsız hale gelebilmekte ve bu durum da kamu gelir-gider dengesi üzerinde bir takım tahribatlara yol açarak, kamu borç miktarının artmasına katkı sağlayabilmektedir.

Hazırlanacak olan bu çalışmada etnik farklılık kavramı ile kamu borcu arasındaki ilişki ele alınarak, etnik farklılık düzeyinin kamu borcu üzerindeki etkisi yatay kesit veri analiz yöntemi ile AB ülkeleri ve Türkiye için test edilecektir. Çalışmada öncelikle etnik farklılık-kamu borcu ilişkisi teorik olarak ortaya konulacaktır. Daha sonra ise, etnik farklılık kavramının, kamu borcu üzerindeki etkisi ampirik olarak test edilecektir.

\section{Etnik Farklılık ile Kamu Borcu İlişkisi}

Son dönemlerde, etnik farklılığın, devletin etkinliğini ve makroekonomik göstergeleri belirleyen önemli bir değişken olduğu fikri yaygınlaşmaktadır (Feldmann, 2012: 192; Montalvo \& Querol, 2005: 293; Campos vd., 2011: 13). Etnik olarak kutuplaşmış toplumların, birçok durumda sosyal ve ekonomik açıdan en iyi politikaları seçme olasılığının daha düşük olduğu ve bundan dolayı verimsiz politikalara yöneldiği ifade edilmektedir (Collier, 1998: 2; Alesina \& Spolaore, 1997: 1046; Easterly \& Levine, 1997: 2; Dollar \& Svenson, 2000: 906). Etnik farklılığın fazla olduğu ülkeler; daha müdahaleci olmakla birlikte, yüksek yolsuzluklar (Ata, 2009: 245), bürokratik gecikmeler, etkinsiz ve yüksek kamu harcamaları, vergi kanunlarına daha fazla muhalefet olma isteğinden dolayı düşük kamu gelirleri gibi hükümet etkinliğinin düşük olduğu ülkelerdir. Bu konuda yapılan birçok analitik çalışma da bu sonucu doğrular bulgular ortaya koymaktadır (Feldmannn, 2012: 192). Bu sonuçlar etnik farklılığın, hükümetin etkinliği üzerinde olumsuz etkiler yarattığının ve etnik grupların, politik ve sosyal çıkar gruplarının kaynakların bölüşümü için yaptıkları iktidar savaşının bir göstergesidir. Fakat ülkelerin yoksulluk düzeyinin kontrol edildiği, belli bir refah düzeyinin yakalandığ 1 , demokrasinin yerleştiği toplumlarda bu durum daha az görülmektedir. Bundan dolayı etnik farklılığın makroekonomik etkileri, az-gelişmiş ya da gelişmekte olan ülkelerde daha yoğun görülmektedir (Muter \& Gökbunar, 2003: 65; Collier, 1998: 5).

Etnik kutuplaşmanın fazla olduğu sosyal yapı, kamu açıkları ve kamu borçlanmasının da artış nedenleri arasında ifade edilebilir. Zira siyasal karar alma sürecinde yer alan seçmenler, politikacılar, bürokratlar baskı ve çıkar grupları, politik ve ekonomik karar verme sürecinde karşılıklı çıkar amaçları doğrultusunda kamu açıklarının oluşumu ve boyutları üzerinde önemli etkilere sahip olabilmektedir (Kuijs, 2000). Seçmenler her zaman devletin vereceği hizmetlerden en yüksek fayda sağlamayı ve refah seviyelerini yükseltmeyi, politikacılar seçmenlerin hoşuna gidecek politikalar yürüterek oylarını artırmayı, bürokratlar bütçe maksimizasyonunu sağlamayı, baskı ve çıkar grupları ise politikacıları etkileyerek alınan kararların kendi çıkarlarına uygun olmasını amaçlamaktadırlar. Bu bağlamda politik süreçte her zaman mübadelenin söz konusu olduğu söylenebilir (Koç, 2009: 64). 
Etnik kutuplaşmanın fazla olduğu toplumlarda, farklı gruplar tarafindan rant kollama faaliyetlerinin yoğun bir şekilde yaşanmasına bağlı olarak etkin politikalar üretilememektedir. (Schüler \& Weisbrod, 2010: 460; Posner, 2004: 852). Bu durum, eğitim, sağlık, altyapı gibi çeşitli kamu mal ve hizmetlerin arzı hususunda antlaşmazlıkların yaşanmasına yol açabilmektedir. Yüksek düzeyde etnik farklılık; ekonomik büyümeyi ve kalkınmayı olumsuz etkilemekte ve optimal olmayan politikaların seçilmesine neden olmaktadır (Easterly \& Levine, 1997: 2). Örneğin ABD'de etnik farklılığın yüksek olduğu bazı idari bölgelerde daha çok harcama yapıldığı, daha çok borç alındığı görülmekle birlikte yapılan bu fazla harcamaların çok azının eğitim ve yol gibi kamu hizmetlerine gitmesi dikkat çekmektedir (Çaha \& Yüksel \& Durak, 2006: 70). Diğer taraftan, yüksek etnik farklılığın, ekonomiler için her zaman bu olumsuz sonuçları doğurması söz konusu olmayabilir. Eğer, multi-etnik özelliğe sahip ülkeler fikir ayrılıklarını yapıcı bir şekilde idare etmelerine imkân veren ve mali yönetime de yardımcı olabilen gelişmiş politik kurumlara sahip olabilir ise, bu tür olumsuzluklar daha az ya da hiç görülmeyebilir (Lavigne, 2006: 6).

Etnik farklılığın yüksek olduğu ülkelerde, iktidara gelen hükümetler tarafından, devlet politikalarının diğer grupların cezalandırılması, muhalefet haklarının sınırlandırılması, kamu mal ve hizmetlerinden diğer grupların yararlanmasının engellenmesi için tasarlanması oldukça sık karşılaşılan bir durumdur (Posner, 2004: 853-854). Böyle bir planlama ise çoğunlukla kamu kaynaklarının kullanımında nitelik olarak bir artışa ama nicelik ve kalite açısından ise etkin olmayan sonuçlara yol açar. Ayrıca, kamu mallarının niteliği ve miktar üzerindeki anlaşmazlıklar sebebiyle heterojen toplumlar, hem bu mallardan daha az talep ederler hem de bu mal ve hizmetlerin finansmanı noktasında çok da istekli olmazlar. Böylelikle kamu mali dengesi bozulur ve borçlanma gereksinimi ortaya çıkar (Alesina vd. 1999; Schüler \& Weisbrod, 2010: 460; Collier, 1998: 7).

Kuijs (2000)'e göre, etnik farklılık, kamu harcamalarının kalitesini düşürmektedir. Yazara göre, heterojen toplumlarda, homojen toplumlardan farklı olarak, kamusal mal ve hizmet arzından sorumlu olan kamu görevlileri, hizmet sunulan ortalama vatandaş ile kendini daha az tanımlamaktadır. Ayrıca kamu çalışanları, kamu sisteminin resmi amaçları ile de kendilerini daha az tanımlayabilirler. Dolayısıyla, kamusal mal ve hizmet arzı ile ilgili alanlarda daha fazla rant kollama ve adam kayırma davranışları görülebilir. Bu durum, kamu görevlilerini, esas görevleri olan kamu hizmeti ve mallarını sağlamaktan alıkoyabilir ve neticede, kamu harcamaları heterojen toplumlarda daha az verimli fakat daha büyük miktarda gerçekleşmiş olabilir.

Hossain ve Chowdhury (1998), gelişmekte olan ülkelerde kamu açıklarının politik iktisadi nedenleri olarak makroekonomik popülizm ve firsatçılığı göstermektedir. Makroekonomik popülizmde hükümetler geniş kitleleri değil, küçük grupları memnun edecek harcamalar yaparlar. Makroekonomik firsatçılıkta ise, demokratik olmayan rejimler varlıklarını devam ettirebilmek ve meşruiyetlerini kabul ettirebilmek için belirli kesimleri memnun edecek kamu harcamalarına öncelik verirler. Çalışmaya göre etnik farklılığın yüksek olduğu toplumlarda, çıkar gruplarının bu yönde baskısı yoğun bir şekilde görülmektedir ve bu durum kamu açıklarına yol açmaktadır. 
Easterly ve Levine (1997), Afrika ülkeleri ile diğer dünya ülkeleri için yaptıkları çalışmada, çıkar gruplarındaki kutuplaşmanın rant kollama faaliyetlerini artırdığı, kamu malları üzerindeki uzlaşıyı azalttığı ve uzun dönemli büyüme üzerinde negatif etkiler yarattığı yolundaki teorileri destekler nitelikte sonuçlar bulmuştur. Ayrıca yazarlar yaptıkları bu çalışmalarında, etnik farklılığın, sosyal ve politik ayırımların etkin politikalar üretilmesini engellediğini göstermişlerdir. Ayrıca finansal derinlik, mali açıklar, eğitim, altyapı gibi büyümeyi etkileyen birçok politika değişkeninin etnik farklılık ile bağlantılı olduğu sonucuna ulaşmışlardır.

Bu çalışmaların yanı sıra, Hodlera ve Knight (2012), Montalvo ve Querol (2005), Annett (2001), Dollar ve Svenson (2000), Alesina ve Spolaore (1997), Sachs ve Warner (1997) ve Mauro (1995), etnik farklılığın temel makroekonomik büyüklükler ve kamu borcu üzerindeki etkisini konu olan çalışmalarda bulunmuşlardır. Yazarlar yaptıkları bu çalışmalar neticesinde, etnik farklılığın yüksek olmasının başta ekonomik büyüme, kamu borcu gibi temel makroekonomik dinamikleri olumsuz yönde etkilediği sonuçlarına ulaşmışlardır.

\section{Model ve Veri Kaynakları}

Kamu borcu ile etnik farklılık arasındaki ilişkiyi analiz etmeye yönelik olarak hazırlanan bu çalışmada, kurumsal faktörlerin ve etnik farklılığın kamu borcu üzerindeki etkisi araştırılacaktır. Bu çerçevede AB Üyesi Ülkeler ve Türkiye için ve 2014 dönemi baz alınarak, "etnik farklılı̆̆ın kamu borcu üzerindeki etkisi" yatay-kesit yöntemi ile test edilecektir. Yapılacak olan bu çalışma sonucunda, kamu borcu ve etnik farklılık arasında bir ilişkinin olup olmadığg, eğer böyle bir ilişki varsa bu ilişkinin pozitif veya negatif yönlü mü olduğu ortaya konulmaya çalışılacaktır. Bu çalışma kapsamında ele alınan ülkeler ve bu ülkelere ait etnik farklılık endeksi değerleri Tablo 1'de gösterilmiştir.

Tablo: 1

Modelde Yer Alan Ülkelere ait Etnik Farklılık Endeksi

\begin{tabular}{|l|c|l|c|}
\hline Almanya & 0.227 & Çek Cumh. & 0.322 \\
\hline Avusturya & 0.126 & Estonya & 0.511 \\
\hline Belçika & 0.567 & Macaristan & 0.308 \\
\hline İngiltere & 0.324 & Slovakya & 0.332 \\
\hline Danimarka & 0.128 & Polonya & 0.099 \\
\hline Finlandiya & 0.132 & Slovenya & 0.231 \\
\hline Fransa & 0.272 & Türkiye & 0.342 \\
\hline Hollanda & 0.077 & Latvia & 0.585 \\
\hline İ́landa & 0.171 & Litvanya & 0.330 \\
\hline İspanya & 0.502 & Malta & -- \\
\hline İsveç & 0.337 & Bulgaristan & 0.299 \\
\hline İtalya & 0.154 & Kibris & 0.350 \\
\hline Yunanistan & 0.186 & Hırvatistan & 0.375 \\
\hline Portekiz & 0.040 & Romanya & 0.300 \\
\hline Lüksemburg & 0.596 & & \\
\hline
\end{tabular}




\subsection{Ampirik Model}

Çalışmada kullanılacak olan ekonometrik modelin temel amacı, kurumsal faktörlerin ve etnik farklılığın kamu borçları üzerindeki etkilerini saptamaktır. Bu çerçevede oluşturulacak ekonometrik model kapsamında, Etnik Farklılık, Yarg1 Bağımsızlığı, Regülasyonların Etkinliği, Kamu Harcamalarındaki Savurganlık, Politik İstikrar Düzeyi değişkenleri modele açıklayıcı değişken olarak dâhil edilmiştir. Kamu borcu ise modelin bağımlı değişkenidir.

Kurumsal faktörlerin kamu borçları üzerindeki etkisi belirlenirken Lavigne (2006) ve Şahbaz, vd. (2013)'nin çalışmalarında kullanılan politik ve kurumsal değişkenler esas alınmıştır. Modelinin matematiksel ifadesi ise şu şekilde gösterilmektedir;

$$
\operatorname{lnKB_{i}}=\beta_{0}+\beta_{1} \mathrm{EF}+\beta_{2} \mathrm{YB}+\beta_{3} \mathrm{KRY}+\beta_{4} \mathrm{KHS}+\beta_{5} \mathrm{PI}+\varepsilon_{\mathrm{i}}
$$

Burada $\ln K B_{\mathrm{i}}$ doğal logaritması alınmış kamu borçlarını gösterirken; açıklayıcı değişkenler ise EF, YB, KRY, KHS ve Pİ; sirasıyla etnik farklılık endeksini, yargı bağımsızlığını, kamu regülasyonların yükünü, kamu harcamalarındaki savurganlığı ve politik istikrarı göstermektedir. $\beta_{0}$, sabit terimi, $\beta_{1}, \beta_{5}$ eğim parametrelerini $\varepsilon_{\mathrm{i}}$ ise hata terimini göstermektedir.

\subsection{Araştırmada Kullanılan Veri Setleri ve Kaynaklar}

Çalışmada kullanılan modelde yer alan bağımlı ve bağımsız değişkenler ve bu verilerin kaynakları aşağıda açıklanmaktadır. Modeldeki değişkenlere ait veriler 2014 yılına aittir.

Çalışmada kullanılan ekonometrik model için bağımlı değişken olan Genel brüt kamu borcu (KB) ile Maastricht Kriterleri çerçevesinde belirlenen tanım kullanılmıştır. Buna göre kamu borcu ile sadece merkezi hükümetin değil, mahalli idareler, fonlar, kamu iktisadi teşekkülleri, özelleştirme kapsamındaki kuruluşlar ve sosyal güvenlik kurumları gibi diğer kamu kurum ve kuruluşlarını da kapsamaktadır. Genel brüt kamu borcu verileri, AB'nin istatistik kolu olan Eurostat ${ }^{1}$ internet veri sayfasından alınmıştır. açıklanmıştır:

Modeldeki açıklayıcı değişkenlere ait verilerin tanımı ve kaynağı ise aşağıda

Çalışmadaki temel açıklayıcı değişken etnik farklılıkla ilgili veri olarak, ülkelerdeki etnik farklılığı gösteren etnik farklılık endeksi kullanılmıştır. Literatürde etnik 
farklılık üzerine yapılan ampirik çalışmaların birçoğunda, etnik bölünmüşlüğü (ya da çeşitliliği) ölçmek için, etnik farklılıkla (EF) ilgili endeksler kullanılmaktadır (Fearon, 2003: 206; Montalvo \& Querol, 2005: 300). Bu endeksler içerisinde en çok kullanılanı, Taylor ve Hudson (1972) tarafından Atlas Nadorov Mira (1964) verilerine dayanılarak oluşturulan, "Etnik farklılık endeksi (index of ethno-linguisticfractionalization)"2 olmaktadir (Posner, 2004: 849). Daha sonraları ise Taylor ve Hudson'un etnik farklılık endeksinin hesaplama prosedüründen hareketle yeni ve güncel veriler ile yeni endeksler oluşturulmuştur. Bu çalışmada da, ülkelerin etnik farlılığını belirlemek için Fearon (2003) hazırlamış olduğu endeksi kullanılmıştır. Bunun nedeni hem verilerin güncelliği hem de bu konu ile yapılan çalışmalarda sıklıkla atıf almasıdır. Bu endeks 0 ile 1 arasındaki değerlerden oluşmaktadır. 0'a yaklaşan değerler, etnik farklılığın düşük seviyelerde olduğunu; 1 'e yaklaşan değerler ise etnik farklılığın yüksek değerlerde olduğunu ifade etmektedir (Fearon, 2003: 208). Veri kaynağı Fearon (2003)'tür.

Çalışmada kullanılan diğer açıklayıcı değişkenlerden Yargl Bă̆ımsızlı̆̆l, Kamusal Regülasyonların Yükü (Burden of Government Regülation) ve Kamu Harcamalarındaki Savurganlık (Wastefulness of Government Spending) endeksleri, "The Global Competitiveness Report 2014-2015" den elde edilmiştir. Bu endeks değerleri 1 ile 7 arasında değerler almaktadır. Örneğin yargı bağımsızlığını gösteren değişken her bir AB ülkesindeki yargının ne ölçüde hükümet üyeleri, vatandaşlar, ya da firmaların etkilerinden bağımsız olduğunu göstermektedir. 1 değeri yargının aşırı bir biçimde hükümet üyeleri, vatandaşlar, ya da firmaların davranışlarından etkilendiğini, 7 değeri ise yargının yüksek derecede bağımsız olduğunu göstermektedir. Kamusal Regülasyonların Yükü endeks değerinde 1 kamusal düzenlemelerin yükünün fazla olduğu durumu, 7 ise yükün olmadığ durumu göstermektedir. Ülkelerdeki kamu harcamalarındaki savurganlık endeksi 1 ile 7 arasındaki değerlerden oluşmaktadır. 1 kamu harcamalarındaki savurganlığın fazla olduğu durumu 7 ise kamu harcamalarının israf edilmediği harcamaların verimli olduğu durumu göstermektedir.

Politik istikrar değişkeni, Dünya Bankası tarafından Kaufmann, Kraay ve Mastruzzi'ye hazırlatılan “The Worldwide Governance Indicators, 2015” den alınmıştır. Endeks değeri $-2,5$ ile $+2,5$ arasında olup, $+2,5$ değerine yaklaştıkça politik istikrar artmakta, tam tersine $-2,5$ değerine doğru yaklaştıkça politik istikrarın azaldığını göstermektedir.

Burada: $\pi_{i}$; belli bir etnik gruba (i) ait olan insanların oranını göstermektedir. Temel olarak bu endeks, rastgele seçilen iki kişinin ülkede ait olabileceği etnik grubu belirlemek için yapılan bir ölçüm yöntemidir. Bu nedenle, grup saylsı artarsa FRAC'de yükselir (Fearon, 2003, 208; Montalvo \& Querol, 2005, 300). 
Model aşağıdaki şekilde tanımlanmıştır:

$\mathrm{KB}=\mathrm{f}(\mathrm{EF}, \mathrm{YB}, \mathrm{KRY}, \mathrm{KHS}, \mathrm{PI})$

Burada:

KB: Genel Brüt Kamu Borçlarını (logaritmik)

EF: Etnik Farklılık Endeksini

YB: Yargı Bağımsızlığını

KRY: Kamusal Regülasyonların Yükünü

KHS: Kamu Harcamalarındaki Savurganlığı

Pİ: Politik İstikrar Düzeyini ifade etmektedir.

Yukarıda tanımlanan değişkenlerin kaynakları ve kamu borcu üzerinde olması beklenen etkileri ve Tablo 2'de gösterilmiştir.

Tablo: 2

\section{Değişkenlerin Kaynă̆ı ve Beklenen İşaretleri}

\begin{tabular}{|l|l|c|}
\hline Değişken & Değişkenin Kaynă̆ı & Beklenen İşaret \\
\hline Etnik FarklılıkEndeksi & Fearon (2003) & + \\
\hline $\begin{array}{l}\text { Yargı Bağımsızlığı } \\
\text { (Hukuk Sisteminin Etkinliği) }\end{array}$ & Global Competitiveness Reports (2014-2015) & - \\
\hline Kamusal Regülasyonların Yükü Endeksi & Global Competitiveness Reports(2014-2015) & - \\
\hline Kamu Harcamalarındaki Savurganlık Endeksi & Global Competitiveness Reports(2014-2015) & - \\
\hline Politik İstikrar Endeksi & Government Indicator-World Bank (2012) & - \\
\hline
\end{tabular}

\subsection{Tahmin Sonuçlarının Değerlendirilmesi}

Tahmin edilen modelde, bağımlı değişken olan kamu borcu ile bağımsız değişkenler olan Etnik Farklılık, Yargı Bağımsızlığı, Kamusal Regülasyonların Yükü, Kamu Harcamalarındaki Savurganlık ve Politik İstikrar Düzeyi değişkenleri arasındaki ilişki incelenmiştir. Söz konusu değişkenler 28 AB üyesi ülke ve Türkiye için ve 2014 yılı verileri kullanılarak yatay kesit analiz yöntemi ile tahmin edilmiştir.

Yatay kesit yönteminin kullanıldığı çalışmalarda sıklıkla karşılaşılan temel problem, değişen varyans sorunudur. $\mathrm{Bu}$ nedenle yatay kesit analizlerinde, tahminlerin değişen varyans sorununun giderilerek yapılması gerekmektedir. Bu çalışmada değişen varyans sorununun giderilmesi için, en yaygın ve tercih edilen yöntem olan, "White heteroskedasticity-consistent standard errors \& covariance" yaklaşımı (Wooldridge, 2001: 55) kullanılarak model tahmin edilmiştir. Böylelikle değişen varyans sorunu giderilmek suretiyle tahminler elde edilmiştir. 
En küçük kareler (EKK) yöntemi ile elde edilen tahmin sonuçları Tablo 3 'te verilmiştir. Tahmin edilen ekonomik modele ait $\mathrm{R}^{2}$ değeri, $0,53^{34}$ olarak saptanmıştır. $\mathrm{Bu}$ çerçevede modelden elde edilen $\mathrm{R}^{2}$ değerinin düşük olmaması modelin bir bütün olarak anlamlılığını ortaya koymaktadır. Ayrıca model yer alan eğim katsayılarının birlikte anlamlılığını test eden F istatistik sonuçları da modelin anlamlılığını doğrulamaktadır. Dolayısıyla çalışmadaki model, gerek $\mathrm{R}^{2}$ gerekse $\mathrm{F}$ istatistik sonuçlarına göre anlamlılık göstermektedir.

Tablo: 3

\section{AB Ülkelerinde Yolsuzluğun Kamu Borçları Üzerindeki Etkisi}

\begin{tabular}{|c|c|c|c|}
\hline \multicolumn{4}{|c|}{ Bağımlı Değişken: LNKB } \\
\hline Değişken & Katsay $^{\mathrm{H}}$ & $\mathrm{t}$ istatistiği & p-değeri \\
\hline $\mathrm{EF}$ & 2.471 & 2.208 & $0.0390 * *$ \\
\hline KRY & -1.810 & -4.614 & $0.0002 * * *$ \\
\hline YB & -1.211 & -4.111 & 0.0005 *** \\
\hline PI & -1.998 & -2.161 & $0.0429 * *$ \\
\hline KHS & -0.847 & -1.711 & $0.0976^{*}$ \\
\hline Sabit Terim & 14.112 & 10.444 & $0.0000^{* * * *}$ \\
\hline$\overline{\mathrm{R}^{2}}$ & \multicolumn{3}{|c|}{0.534} \\
\hline F-statistic & \multicolumn{3}{|c|}{4.586} \\
\hline Prob(F-statistic) & \multicolumn{3}{|c|}{$0.005989 * * *$} \\
\hline $\begin{array}{l}\text { ***:\%1 Anlamlllk düzeyina } \\
\text { **\%5 Anlamlıllk düzeyinde } \\
\text { *\%10 Anlamlllk düzeyinde } \\
\text { H: Değişen Varyansin tespi } \\
\text { göstermektedir. Bu yolla kat } \\
\text { göre katsayllartn anlaml olv }\end{array}$ & $\begin{array}{l}\text { sel olarak anla } \\
\text { l olarak anlaml } \\
\text { lolarak anlaml } \\
\text { üzerine, değiş } \\
\text { ğişmemekte, an } \\
\text { larl önem arz e }\end{array}$ & tan & $\begin{array}{l}k \text { yapilan yeni } \\
\text { yeni tahmin s }\end{array}$ \\
\hline
\end{tabular}

Elde edilen ampirik sonuçlara göre, etnik farlılık endeksi ile kamu borçları arasında \%5 anlamlılık düzeyinde istatistiksel olarak anlamlı bir ilişki bulunmaktadır. İlişkinin niteliği açısından değerlendirildiğinde pozitif yönlü bir etki tespit edilmiştir. Başka bir ifade ile etnik farklılık düzeyindeki 1 birimlik artış kamu borçlarını 2,471 birim artırmaktadır. Bu durum, çalışmanın teorik kısmında ifade edilen görüşlerin, analitik olarak da ispatlandığı sonucunu doğurmaktadır.

Hazırlanan bu çalışma, diğer bir açıklayıcı değişken olan kamusal regülasyonların yükünün, kamu borçları üzerinde $\% 1$ anlamlılık düzeyinde istatistiksel olarak anlamlı ve

4 Bağımlı değişkendeki değişmelerin ne kadarının bağımsız değişkendeki değişmeler tarafindan açıklandı̆̆ını gösteren $R^{2}$ değeri ekonometrik yöntemler açısından değerlendirildiğinde düşük görülebilir. Bununla birlikte yatay kesit verileri ile yaplan tahminlerden elde edilen $R^{2}$ 'lerin genel olarak küçük olduğu bilinmektedir. Studenmund (1992: 47) yatay kesit verilerinde 0.50 büyüklüğ̈̈ndeki bir $R^{2}$ 'nin iyi bir uygunluk olduğunu belirtmiştir (Ă̆lr \& Kar 2010: 167). 
negatif yönlü bir ilişki olduğunu ortaya koymaktadır. Çalışmanın tahmin sonuçlarına göre, kamusal regülasyonların yükü endeksindeki 1 birimlik bir artış (kamusal regülasyonların yükünün azalması) kamu borçlarında -1,810 birimlik bir düşüşe neden olmaktadır.

Çalışmada, hukuk sisteminin etkinliğini ölçen yargı bağımsızlığı değişkeninin, kamu borcu üzerinde \%1 anlamlılık düzeyinde istatistiksel olarak anlamlı ve negatif yönlü bir etkiye sahip olduğu sonucuna ulaşılmıştır. Bu durumda yargı bağımsızlık endeksindeki 1 birimlik bir artış (hukuk sistemi etkinliğinin artması) kamu borçları üzerinde -1,211 birimlik bir düşüşe neden olmaktadır. Başka bir ifade ile yargı bağımsızlığının artması AB ülkelerinde kamu borçlarını azaltan bir unsurdur.

Bir başka açıklayıcı değişken olan politik istikrar düzeyinin, kamu borçları üzerinde $\% 5$ anlamlılık düzeyinde istatistiksel olarak anlamlı ve negatif yönlü bir ilişkiye sahip olduğu sonucuna ulaşılmıştır. Bu durumda politik istikrar düzeyindeki 1 birimlik bir artış kamu borçlarında -1,998 birimlik bir azalışa neden olmaktadır. Başka bir ifade ile AB ülkelerinde politik istikrarın artması, kamunun borçlarını azaltmaktadır.

Tahmin sonuçları, kamusal harcamalardaki savurganlığın, kamu borçları üzerinde $\% 10$ anlamlılık düzeyinde istatistiksel olarak anlamlı ve negatif yönlü bir etkiye sahip olduğunu ortaya koymaktadır. $\mathrm{Bu}$ durumda kamu harcamalarındaki savurganlık endeksindeki 1 birimlik bir artış (kamu harcamalarındaki israfın azalması) kamu borçlarında -0.847 birimlik bir düşüşe neden olmaktadır. Dolayısıyla kamu harcamalarında israfın önlenmesinin kamu borçlarını azaltan bir unsur olduğu ifade edilebilir.

Sonuç olarak 28 AB ülkesinin 2014 yılı verileri ile yapılan bu çalışmada, kurumsal faktörlerdeki iyileşmelerin ve etnik farklılıktaki azalmanın kamu borçlarını azaltan bir etkiye yol açtığı bulgusuna ulaşılmıştır.

\section{Sonuç}

Geleneksel anlayış gereği, ekonomik hayatı açıklamada kullanılan ekonomik değişkenler, makroekonomik dinamikleri yeterli biçimde açıklamakta başarısız olmuşlardır. Bunun üzerine, son dönemlerde, makroekonomik politikalara yönelik "politik ekonomi yaklaşımı" olarak bilinen yeni analitik çalışmalar, makroekonomik değişkenler üzerinde politik ve kurumsal faktörlerin önemi ve etkisi üzerine odaklanmıştır.

$\mathrm{Bu}$ bakış açısı doğrultusunda, kamu borcu olgusu ve buna yol açan faktörler konusu, gerek ekonomik gerekse politik-kurumsal unsurlar kapsamında araştırılmaya başlanmıştır. Günümüzde, kamu borcunun, sosyal ve kurumsal belirleyicileri üzerine yaygınlaşan bir literatür oluşmakla beraber, mevcut durumun hala yeterli düzeyde olmadığ 1 ifade edilmektedir. 
Ekonomilerde belirli bir dönem içinde kamu gelirleri ile kamu giderleri arasındaki fark olarak tanımlanan kamu açığı/kamu borcu, içinde bulunduğu toplumun ekonomik, politik, sosyal ve kurumsal yapısından etkilenebilmektedir.

Kamu borcu, günümüzde gerek gelişmiş, gerekse gelişmekte olan ülkelerde farklı boyutlarda olmak üzere makroekonomik dengeler üzerinde olumsuz sonuçlara yol açan önemli bir ekonomik ve mali sorun olarak karşımıza çıkar. Bu sorunun ortaya çıkmasına yol açan sosyal unsurlardan biri olarak toplumun etnik yapısı vurgulanmaktadır.

Etnik açıdan kutuplaşmanın fazla olduğu yada etnik farklılığın yüksek olduğu heterojen toplumlarda, kamu mal ve hizmetlerinin sunumunda etkinliğin azalacağ kayırmanın ya da rant kollama faaliyetlerinin artacağı, kamu harcamalarındaki etkinlik kaybından dolayı, harcama miktarının artacağı ve buna bağlı olarak mali disiplinin bozulacağı beklenen bir sonuçtur. Aynı zamanda, heterojen toplumlarda, kamu mal ve hizmetlerin finansmanına karşı toplumsal bir direncin oluşacağı muhtemel bir durumdur. Böyle bir durum ise kamu gelirlerinin azalmasına yol açarak, kamu borcuna olan gereksinimin artmasına neden olmaktadır. Sonuç olarak, etnik farklılığın yüksek olduğu toplumlarda, kamu gelir-gider dengesinin olumsuz etkilenerek, kamu borcu düzeyinin artmasına yol açtığı ifade edilebilir. Ama bu durum, etnik farklılığın yüksek olduğu her ekonomi için gerçekleşmeyebilir. Eğer, ülkeler, fikir ayrılıklarını yapıcı bir şekilde idare etmelerine imkân veren ve mali yönetime de yardımcı olabilen gelişmiş politik kurumlara sahip olabilir ve aynı zamanda etnik çatışmaları azaltıcı kurumsal yapıları ortaya çıkarırlarsa, bu tür olumsuzluklar daha az ya da hiç görülmeyebilir.

Hazırlanan bu çalışmada, etnik farklılık ile kamu borcu arasındaki etkileşim yatay kesit yöntemi kullanılarak tahmin edilmiştir. Bu çerçevede kamu borcunun, politik ve kurumsal belirleyicileri olarak; etnik farklılık düzeyi ve diğer kontrol değişkenlerinden oluşan bir model oluşturulmuş (Yargı Bağımsızlığı, Kamusal Regülasyonların yükü, Kamu Harcamalarındaki Savurganlık, Politik İstikrar Düzeyi) ve test edilmiştir. Çalışmadan elde edilen bulgulara göre, etnik farklılığın yüksek olduğu heterojen toplumlarda, kamu borcu düzeyinin de yüksek olduğu istatistiksel olarak doğrulanmıştır. Yani, ülkeler, farklı etnik yapılardan oluşuyor ve yüksek bir etnik farklılaşmanın olduğu bir sosyal yapı sergiliyorlarsa, bu durum kamu borçlarında da artışa yol açıyor demektir. Çalışmadaki tahmin sonuçlarına göre, etnik farklılık düzeyindeki 1 birimlik artış kamu borçlarını 2,471 birimlik artırmaktadır. Bu durum, çalışmanın teorik kısmında ifade edilen görüşlerin, analitik olarak da ispatlandığı sonucunu doğurmaktadır.

Bununla birlikte modelde kullanılan diğer kurumsal unsurlar ile kamu borcu arasında da istatistiksel olarak anlamlı ve beklenen yönde bir etkileşim olduğu sonucuna ulaşılmıştır. Buna göre, yarg1 bağımsızlığı, kamusal regülasyonların yükü, kamu harcamalarındaki savurganlık, politik istikrar düzeyi gibi politik ve kurumsal yapılarda gelen olumlu bir değişim, kamu borcunu azalmaktadır. 
Sonuç olarak, günümüz ekonomilerin en temel makroekonomik sorunlarından biri olan yüksek kamu borçlarından kurtulabilmek için sadece ekonomik faktörleri irdelemek ve o yönde tedbirler almak yeterli olmayabilir. Zira kamu borçları, sadece ekonomik faktörlerle açıklanamayacak kadar karışık ve çok yönlü etkileşimi olan bir sorundur. Bu kapsamda, kamu borçlarını azaltmak ve ekonomi üzerindeki olumsuz etkilerini bertaraf etmek amaçlanıyor ise, toplumun, ekonomik, politik, sosyal ve demografik unsurlarının da göz önünde tutulması ve bu alanlarda da bir takım tedbirler alınması önem arz etmektedir.

\section{Kaynaklar}

Ağır, H. \& M. Kar (2010), “Türkiye'de Elektrik Tüketimi ve Ekonomik Gelişmişlik Düzeyi İlişkisi: Yatay Kesit Analizi”, Sosyoekonomi, 2010, Özel Say1.

Alesina, A. \& E. Spolaore (1997), “On the Number and Size of Nations”, Quarterly Journal of Economics, 112(4), 1027-1056.

Annett, A. (2001), "Social Fractionalization, Political Instability, and Size of Government", IMF Staff Papers 48(3), 561-592.

Ata, A.Y. (2009), Kurumsal İktisat Çerçevesinde Yolsuzluğun Fırsat ve Motivasyonları: AB Ülkeleri Üzerine Bir Inceleme, İktisadi Araştırmalar Vakfi Yayınları, İstanbul.

Campos, N. \& V. Kuzeyev (2007), “On the Dynamics of Ethnic Fractionalization”, American Journal of Political Science, 51(3), 620-639.

Collier, P. \& A. Hoeffler (1998), “On Economic Causes of Civil War”, Oxford Economic Papers, 50(4), 563-73.

Çaha, H. \& H. Yüksel \& F. Durak (2006), “Küresel Bir Sorun Olarak Yolsuzluk”, Yolsuzluk, Ed. S. Aydın, Turhan Kitabevi, Ankara, 45-86.

Dollar, D. \& J. Svensson (2000), "What Explains the Success or Failure of Structural Adjustment Programs?”, Economic Journal, Royal Economic Society, 110(October), 894-917.

Easterly, W. \& R. Levine (1997), “Africa's Growth Tragedy, Policies and Ethnic Divisions”, Quarterly Journal of Economics, 112, November, 1-39.

Feldmann, H. (2012), "Ethnic Fractionalization and Unemployment”, Economic Letters, 117(1), 192195.

Hodler, R. \& D.S. Knight (2012), "Ethnic Fractionalisation and Aid Effectiveness“, Journal of African Economies, Centre for the Study of African Economies (CSAE), vol. 21(1), 6593.

Hossain, A. \& A. Chowdbury (1998), Open Economy Macroeconomics for Developing Countries, Edward-Elgar Yayınları, 1. Bask1.

Koç, A. (2009) "Kamu Açıklarının Ekonomik, Politik ve Kurumsal Belirleyicileri: Gelişmekte Olan Ülkeler Üzerine Bir Uygulama”, Çukurova Üniversitesi Sosyal Bilimler Enstitüsü, Yayımlanmamıs Doktora Tezi, Adana.

Kuijs, L. (2000), "The Impact of Ethnic Heterogeneity on the Quantity and Quality of Public Spending", IMF WP49.

Lavigne, R. (2006), “The Institutional and Political Determinants of Fiscal Adjustment”, Bank of Canada Working Paper, No. 2006-1. 
Mauro, P. (1995), “Corruption and Growth”, The Quarterly Journal of Economics, 110(3), 681-712.

Montalvo, J. \& M.R. Querol (2005), "Ethnic Diversity and Development", Journal of Development Economics, 76(2), 293-323.

Muter, N.B. \& R. Gökbunar (2003), "Devletin Etkinliği ile İlgili Ekonomik, Politik Kültürel Teoriler”, Celal Bayar Üniversitesi Sosyal Bilimler Enstitüsü Dergisi, 1(1), 53-70.

Posner, D. (2004), "Measuring Ethnic Fractionalization in Africa”, American Journal of Political Science, 48(3), 849-863.

Sachs, J.D. \& A. Warner (1997), "Sources of Slow Growth in African Ecconomies", Journal of African Economies, 6(3), 335-376.

Scheuler, D. \& J. Weisbrod (2010), "Ethnic Fractionalisation, Migration and Growth”, Empirical Economics, 39(2), 457-486.

Şahbaz, A. \& A. Koç \& A.Y. Ata (2013), "Yolsuzluk ve Kamu Borcu İlişkisi: AB Ülkeleri Üzerine Ampirik Bir İnceleme", Akdeniz Üni. İBF. Dergisi, (26), 206-220.

Woo, J. (2003), "Economic, Political, and Institutional Determinants of Public Deficits", Journal of Public Economics, 87(3-4), 387-426.

Wooldridge, J.M. (2001), Econometric Analysis of Cross Section and Panal Data, The MIT Press, Cambridge, London. 
Konu, A. \& A.Y. Ata (2016), "Etnik Farklılık ve Kamu Borcu Üzerine Etkileri: Analitik Bir Bakış Açısı”, Sosyoekonomi, Vol. 24(28), 175-187. 